\title{
LANDASAN HUKUM PEMBERIAN HAK WILAYAH PESISIR DAN PULAU TERHADAP MASYARAKAT ADAT DI PROVINSI KEPULAUAN RIAU
}

\author{
Oleh \\ Eldi \\ Widyaiswara Kementerian Agraria dan Tata Ruang/Badan Pertanahan Nasional \\ Jl. Sisingamangaraja No.2, Selong, Kec. Kby. Baru, Kota Jakarta Selatan, Daerah Khusus \\ Ibukota Jakarta 12110, \\ Email : leditalyusman@gmail.com
}

The aim of this article is to anlyze the legal basis of granting coastal and island territory to indigenous people in the Province of Riau to connected with the issuance of legislation on the management of coastal areas and small islands in the provisions of regulation Number. 27/2007 and the rights of local coastal waters and small islands according to goverment regulation Number 40/1996, especially in clause of 60 starting for granting of business rights, building rights and land rights that are entirely island or bordered by the beach are governed by the goverment regulation and it's regulation. In this article used the normative juridical methodology, the author used in this article study of references that conducted used secondary data, namely collecting data from various literature from the law, books, documents and archieves related to this issue. Thus, the analysis used by collecting data to be processed and analyzed according to the nature of the collected data, for futher presented by the analyst evaluative. This scientific writing shows that the rights of the coastal water exploitation contained in regulation Number 27/2007 abaout PWP3K is one of legal norms governing coastal, but it turns out to cause pros and cons.

Keywords: Regulation Of Granting Coastal And Island Territorial Rights, Indigenious People \& Regulation Number 27/2007

\section{PENDAHULUAN}

Pembangunan yang begitu pesat di

kawasan Asia Tenggara, termasuk Indonesia pada dekade yang lalu memang telah dapat menaikkan taraf hidup masyarakat di segala bidang. Akan tetapi pembangunan yang berlangsung cepat tersebut terkadang membawa dampak. Begitupun terhadap lingkungan wilayah pantai dengan berbagai pembangunan yang dilakukan telah menimbulkan kerusakan ataupun bencana ekologis di kawasan pantai dan pesisir.

Berhubung pada saat ini banyak terdapat permohonan-permohonan yang diajukan oleh perseorang dan badan hukum untuk mendapatkan hak atas tanah yang seluruhnya merupakan pulau atau yang berbatasan dengan pantai, dan sudah lama berlangsung, seperti penguasaan perairan pantai pulau-pulau kecil dan akhir-akhir ini sudah berkembang penguasaan pulau-pulau kecil oleh badan hukum melalui izin pemerintah daerah yang pada umumnya untuk pariwisata.

Kebijakan pemerintah daerah oleh badan hukum dalam bentuk Hak Guna Bangunan di atas hak pengelolaan pemerintah daerah diatas tanah Negara dan pemberian izin lokasi (izin prinsip) atau perjanjian kerja sama, kebijakan tersebut berdasarkan pada persepsi, kondisi dan kebutuhan masing-masing daerah terhadap pembangunan pulau-pulau kecil di daerahnya. Tetapi yang menjadi permasalahannya adalah bahwa sudah banyak dari pemerintah daerah yang memberikan hak kepemilikan pulau-pulau kecil dan berbatasan dengan pantai terutama bagi kabupaten atau kota yang memiliki pulau-pulau kecil yang wilayahnya berbatasan langsung dengan pantai, yang dimana masyarakatnya telah lama mendiami pulau tersebut, namun untuk badan 
hukum pun sudah banyak diberikan terutama untuk kawasan pariwisata.

Berdasarkan Peraturan Pemerintah Nomor 40 tahun 1996 tentang Hak Guna Usaha, Hak Guna Bangunan dan Hak Pakai Atas atas terutama pada pasal 60 yang menyatakan bahwa " pemberian Hak Guna Usaha, Hak guna Bangunan, dan hak Pakai atas Bidang tanah yang seluruhnya merupakan pulau atau yang berbatasan dengan pantai diatur tersendiri dengan Peraturan Pemerintah. Dan penjelasannya " dengan adanya ketentuan ini, maka permintaan hak atas tanah yang baru yang seluruhnya merupakan pulau tidak dilayani sampai dengan ditetapkannya peraturan Pemerintah yang mengatur hal tersebut. Berdasarkan latar belakang tersebut, maka penulis berhasil melakukan identifikasi masalah dan didapatkan beberapa persoalan pokok, yaitu tingkat kemiskinan, sumber daya manusia yang rendah, tingkat pendidikan yang masih kurang, kultur atau budaya dan karakter, bertempat tinggal di pesisir, kerusakan sumber daya pesisir, mata pencaharian sebagai nelayan, rendahnya kemandirian organisasi social desa, serta minimnya infrastruktur dan kesehatan lingkungan di daerah desa pesisir. Yang dimana kesembilan pokok masalah tersebut memberikan andil atas tingginya kerentanan desa yang berada di wilayah pesisir dalam mengahdapi bencana alam dan perubahan iklim.

Dalam artikel ini memiliki batasan masalah yang akan dibahas, yaitu hanya membahas terkait pemberian hak atas tanah masyarakat adat yang berbatasan dengan pantai dan pulau serta landasan hukum pemberian hak atas tanah bagi perseorangan dan badan hukum. Tujuan penulisan arikel ini adalah untuk dapat mengetahui dan manambah pemahaman terhadap peraturan yang berkenaan dengan aspek hukum pemberian hak atas tanah bagi masyarakat hukum adat setempat terutama pada wilayah pesisir dan pulau-pulau kecil bagi eksistensi masyarakat adat. Kemudian yang menjadi rumusan masalah dalam artikel ini adalah apa saja landasan hukum yang digunakan oleh pemerintah daerah dalam pemberian hak wilayah pesisir dan pulau terhadap masyarakat adat di Provinsi Kepulauan Riau ?

\section{METODE PENELITIAN}

Jenis penulisan yang dilaksanakan adalah penelitian normatif, yaitu penelitian terhadap, asas-asas yang mengatur mengenai Hak milik perseorangan dan hak Guna bangunan bagi perusahaan terutama yang berbatasan dengan pantai dan pulau dikaitkan dengan hukum karena Jenis penelitian yang dilaksanakan adalah penelitian yuridis normatif, maka penulis menggunakan studi pustaka, studi pustaka ini dilakukan dengan menggunakan data sekunder yaitu menghimpun data dari berbagai literatur, Literatur yang digunakan adalah Undangundang, Buku-buku, juga Dokumen dan Arsiparsip yang terkait dengan masalah ini. Yang dapat dipertanggung jawabkan secara ilmiah, dan juga sebagai landasan teoritis berupa pendapat-pendapat dari para ahli hukum. Sumber data diperoleh dari Bahan hukum primer, yaitu bahan-bahan hukum yang mengikat, yakni, Pembukaan Undang-undang Dasar 1945, Batang Tubuh Undang-undang Dasar 1945 dan TAP MPR, Peraturan Perundang-undangan yang terkait. Bahan hukum sekunder, yang memberikan penjelasan mengenai bahan hukum primer, antara lain; Undang-undang, PP, hasil-hasil dari penelitian, karya-karya ilmiah dari kalangan hukum.

\section{HASIL DAN PEMBAHASAN}

1. Hasil

\section{a. Tipologi Negara Kesatuan Republik Indonesia}

Indonesia adalah negara kepulauan dengan wilayah yang sangat luas, terdiri dari ribuan pulau dan dua pertiga dari keseluruhan luas wilayah Indonesia merupakan wilayah perairan, Dengan luas wilayah laut Indonesia yang diperkirakan mencapai 5,8 juta $\mathrm{km} 2$. Berdasarkan data Departemen Dalam Negeri Republik Indonesia tahun 2004, jumlah pulau 
di Indonesia tercatat sebanyak 17.504 buah. 7.870 di antaranya telah mempunyai nama, sedangkan 9.634 belum memiliki nama.

\section{b. Wilayah Pesisir di Indonesia}

Wilayah pesisir Indonesia mengandung kekayaan sumber daya alam (di wilayah pesisir) yang sangat beragam baik sumber daya yang dapat diperbarui (seperti perikanan, terumbu karang dan daerah konservasi) maupun sumber daya yang tidak dapat diperbarui (seperti bahan tambang berupa minyak dan gas serta mineral lainnya). Wilayah pesisir juga menjadi pusat pengembangan kegiatan industri, pelabuhan dan pelayaran, pariwisata, agribisnis, pemukiman dan penampungan limbah secara gratis dari segenap aktivitas manusia, baik yang berada di dalam sistem wilayah pesisir maupun yang berada di luarnya (lahan atas dan laut lepas).

\section{Pembahasan}

\section{a. Hak Ulayat Masyarakat Adat Atas Pesisir dan Laut}

Hak ulayat laut merupakan terjemahan dari kata dalam bahasa Inggris, sea tenure. Sudo (1983) yang mengutip Laundgaarde, mengatakan bahwa istilah sea tenure mengacu kepada seperangkat hak dan kewajiban timbal balik yang muncul dalam hubungannya dengan kepemilikan wilayah laut. Sea tenure adalah suatu sistem, dimana beberapa orang atau kelompok sosial memanfaatkan wilayah laut, mengatur tingkat eksploitasi terhadap wilayah tersebut, yang berarti juga melindunginya dari eksploitasi yang berlebihan (over exploitation).

Melengkapi batasan Sudo, seorang ilmuan lain yaitu Akimichi Tomoya (1991) mengatakan bahwa hak-hak kepemilikan (property rights) mempunyai konotasi sebagai memiliki (to own), memasuki (to access) dan memanfaatkan (to use). Baik konotasi memiliki, memasuki maupun memanfaatkan tidak hanya mengacu pada wilayah penangkapan (fishing ground), tetapi juga mengacu pada teknik-teknik penangkapan, peralatan yang digunakan (teknologi) atau bahkan sumberdaya yang ditangkap dan dikumpulkan.
Dengan demikian maka secara teoritis dapat dikatakan bahwa yang dimaksud dengan hak adat kelautan (hak ulayat laut) adalah seperangkat aturan atau praktek pengelolaan atau manajemen wilayah laut dan sumber daya di dalamnya berdasarkan adat-istiadat yang dilakukan oleh masyarakat pesisir pada desa (negeri-negeri untuk Maluku Tengah).

Perangkat aturan atau hak adat kelautan (hak ulayat laut) ini menyangkut siapa yang memiliki hak atas suatu wilayah, jenis sumberdaya yang boleh ditangkap dan teknik mengeksploitasi sumberdaya yang diperbolehkan yang ada dalam suatu wilayah laut.

Sebagaimana telah disebutkan di atas, bahwa hak ulayat laut mengacu pada seperangkat hak dan kewajiban timbal balik yang muncul dalam institusi pemilikan bersama. Istilah pemilikan bersama disini merujuk pada pembagian hak-hak penguasaan bersama di dalam pengelolaan dan pemanfaatan sumberdaya tertentu. Konsep milik jika diterapkan pada sumberdaya mengandung arti sebagai suatu kelembagaan sosial primer yang memiliki susunan dan fungsi untuk mengatur sumberdaya yang lebih didasarkan pada kebiasaan, larangan-larangan dan kekeluargaan. Oleh karena itu institusi atau kepranataan dalam sistem kepemilikan atau penguasaan sumberdaya bersama tidak dapat dilepaskan dari adanya sosial order yang memiliki kekuatan mengikat bagi setiap individu anggota suatu komunitas.

Aturan-aturan yang terbentuk dalam sistem penguasaan bersama itu pada dasarnya merupakan suatu kesadaran kolektif (collective consciousness). Dalam hal ini kesadaran kolektif itu mempunyai dua sifat pokok (Wahyono dkk, 2000 : 8 - 9). Pertama, mengandung pengertian bahwa kesadaran kolektif dari suatu komunitas atau kelompok sosial sesungguhnya berada di luar ke-diri-an dari setiap individu anggota masyarakat. Jadi kesadaran kolektif itu tidak tergantung keberadaannya pada eksistensi dari setiap individu, melainkan sebaliknya, yaitu selalu diwariskan atau disosialisasikan dari suatu 
nenerasi ke generasi berikutnya. Sifat yang kedua, kesadaran kolektif mengandung suatu kekuatan psikis yang memaksa individuindividu anggota kelompok untuk menyesuaikan diri terhadapnya.

Berdasarkan pada gambaran sebagaimana dikemukakan di atas maka dapat dikatakan bahwa fungsi hak ulayat laut dalam suatu komunitas dapat dilihat dari seberapa jauh institusi hak ulayat laut itu memberikan kestabilan struktur sosial suatu komunitas tersebut. Tentang hak ini Brown (Zerner, 1993 : 76)

Melihat uraian diatas, pengertian fungsi pada hak ulayat laut adalah menunjuk pada suatu proses hubungan sosial yang dinamis dalam suatu sistem sosial atau struktur masyarakat tempat hak ulayat laut itu dipraktekkan. Berkaitan dengan ini Robert $\mathrm{K}$ Merton (Zerner, 1993 : 106) mengemukakan bahwa dalam melakukan analisis fungsional pada suatu kepranataan sosial sebaiknya lebih ditekankan pada permasalahan yang konkret, yaitu bagaimana mekanisme sosial sebuah lembaga kepranataan sosial itu berlangsung, seperti antara lain pembagian peran, penyekatan kelembagaan, susunan nilai-nilai, pembagian kerja dan praktek-praktek ritual.

Merton membedakan fungsi kedalam dua hal, yaitu fungsi manifest dan fungsi laten. Menurut Merton sesuatu memiliki fungsi manifest apabila :

"...... those objective consequences contributing to the adjustment or adation of the sistem which are intended and recognized by participant in the system "(dalam Zerner, 1993 : 105).

Adapun fungsi laten berkaitan dengan : .... those which are neither nor recognized. Apabila dikaitkan dengan hak ulayat laut, maka fungsi manifest menunjuk pada pengertian berbagai konsekuensi praktek hak ulayat laut yang disadari oleh setiap anggota masyarakat dalam rangka menjaga keutuhan masyarakat atau integrasi sosial, sedangkan berbagai konsekuensi dari praktek hak ulayat laut yang tidak didasari merupakan fungsi laten dari hak ulayat laut tersebut.

Dalam kaitan ini, Johanes memberikan contoh fungsi-fungsi yang terdapat dalam hak ulayat laut sebagai berikut:

"Costumary marine tenurecan play a number of valuable roles and contempory fisheries management. It can : (1) provide cultural sanctioned rules for allocating marine resources acquitable, apprehending and punishing trangressord and adjudicating disputes (usually without resource to government, thereby greatly reducing administrative cost); (2) function as a from of conservation measure by limiting entry to a fishery and providing the owners with an incentive ti regukate their own harvest; and (3) facilitate more flexible adjustments to changing biological or socio economic conditions affecting the fishery than do government regulation".

Suatu bahasan mengenai hak ulayat laut dalam bentuk yang lebih dinamis lahir dari pertanyaan pokok, yaitu mengapa hak ulayat laut dipraktekkan oleh suatu masyarakat dan factor-faktor apa yang mempengaruhinya. Belum ada suatu teori yang mampu menjawab secara tuntas pertanyaan ini. Akan tetapi cukup banyak hipotetis yang berusaha menjawab pertanyaan ini dengan acuan kasus-kasus tertentu. Ini berarti ada banyak variabel yang mengarah ada atau tidaknya aturan dan praktek hak ulayat laut pada suatu masyarakat. Meskipun demikian, suatu hal yang merupakan kunci mengenai hal ini adalah anggapan bahwa laut merupakan suatu sumberdaya yang bernilai.

Banyak hal yang kemudian mengarah pada anggapan bahwa sumberdaya laut bernilai tinggi atau sebaliknya. Pertama, misalnya tingkat kepentingan laut. Kedua, laut juga bisa dikatakan bernilai jika memiliki sumberdaya, dan kondisi ekologisnya sedemikian rupa sehingga orang mudah mengeksploitasinya. Dalam hal yang terakhir ini, tentu berhubungan pula dengan mudah atau tidaknya proses distribusi berjalan, atau dengan kata lain ada 
atau tidaknya pasar. Kondisi pasar itu sendiri sedikit banyak dipengaruhi oleh masyarakat lain, sehingga kemungkinan intensitas terjadinya proses tukar menukar semakin besar.

Satu variabel yang berbeda dengan variabel-variabel di atas adalah sistem kepercayaan. Pada sistem kepercayaan masyarakat tertentu, laut mungkin dianggap sebagai sumber kehidupannya. Dengan latar belakang kepercayaan ini, maka perlakuan masyarakat terhadap laut berbeda, termasuk masalah yang berhubungan dengan berkembang atau tidaknya hak penguasaan laut tersebut.

Selanjutnya, apabila variabel-variabel di atas diidentifikasikan dalam upaya mencari jawaban mengapa hak ulayat laut dipraktekkan oleh suatu masyarakat, maka jawaban atas variabel-variabel apa yang mempengaruhi berlangsungnya hak ulayat laut, lebih banyak terikat pada suatu variabel kunci yaitu konflik (Pollnac : 1984). Hal ini disebabkan oleh karena konflik merupakan suatu potensi yang cukup kuat atas berubahnya hak ulayat laut. Dalam hal ini perubahan-perubahan yang terjadi sangat bervariasi, dari mulai perubahan isi aturan maupun praktek hak ulayat laut sampai pada perubahan yang menyangkut semakin menguat atau melemahnya praktek pelaksanaan aturan hak ulayat laut tersebut.

\section{b. Hak Ulayat dan Hak Penguasaan Negara}

Hak ulayat tidak sama dengan hak penguasaan Negara yang bersumber dari konstitusi Negara. Hak ulayat yang diakui dan disebut dalam Pasal 3 UUPA. Pengakuan eksistensi hak ulayat adalah wajar, karena hak ulayat berserta masyarakat hukum adat telah ada sebelum terbentuknya UUD 1945 yang memuat konsep hak penguasaan Negara. UUPA sendiri tidak memberikan penjelasan tentang pengertian hak ulayat itu, kecuali menyebutkan bahwa yang dimaksud dengan hak ulayat adalahbeschikkingsrecht dalam kepustakaan hukum adat. Maria S.W. Sumardjono (dalam Abrar Saleng, 2004 : 51) mengartikan masyarakat hukum adat sebagai masyarakat yang timbul secara spontan di wilayah tertentu dengan rasa solidaritas yang besar di antara anggotanya dan memandang yang bukan anggota sebagai orang luar, menggunakan wilayahnya sebagai sumber kekayaan yang hanya dapat dimanfaatkan sepenuhnya oleh anggotanya, pemanfaatan oleh orang luar harus dengan izin dan pemberian imbalan tertentu berupa recognisi.

Dengan demikian hak ulayat menunjukkan adanya hubungan hukum antara masyarakat hukum adat (subjek hak) dan sumber daya alam serta wilayah tertentu (objek hak). Hak ulayat berisi wewenang-wewenang yang menyatakan hubungan hukum antara masyarakat hukum adat dengan sumber-sumber alam/wilayahnya adalah hubungan penguasaan, bukan hubungan pemilikan. Hubungan hukum itu disebut ulayatnya yang bersal dari bahasa Minang yang berarti "wilayahnya" (Boedi Harsono, 1975 : 83).

Berdasarkan pengertian dan pandangan teoritis di atas, maka terdapat indikasi adanya hubungan persamaan dan perbedaan antara hak ulayat dengan hak penguasaan Negara yaitu (Abrar Saleng, 2004 : 52) :

(a) Subjeknya, bagi hak ulayat adalah masyarakat hukum, bukan perorangan, sedangkan bagi hak menguasai Negara adalah Negara.

(b) Objeknya, bagi hak ulayat adalah tanah, air dan sumber-sumber alam (tertentu) dalam wilayahnya, sedangkan hak menguasai Negara lebih luas, sebab selain semua potensi sumberdaya alam yang ada dalam wilayah Negara Indonesia, juga cabang produksi yang penting bagi Negara dan menguasai hajat hidup orang banyak.

(c) Isinya, bagi hak ulayat adalah rangkaian wewenang dan kewajiban yang meliputi : pengaturan, pemberian cara penggunaan sumberdaya alam dan pemeliharaannya, sedangkan bagi hak menguasai Negara adalah sejumlah wewenang dan kewajiban public yang meliputi : pengaturan, pengutrusan serta pengawasan 
penggunaan dan pemanfaatan segenap potensi sumberdaya alam dan cabangcabang produksi untuk sebesarbesarnya kemakmuran rakyat.

(d) Pelaksana, bagi hak ulayat adalah Kepala Persekutuan Hukum atau kepala adat, sedangkan bagi hak penguasaan Negara adalah pemerintah Republik Indonesia.

Berdasarkan perbedaan di atas, maka hak ulayat dapat dipersamakan dengan hak bangsa dan wewenang kepala persekutuan hukum adat dipersamakan dengan hak penguasaan Negara. Ruang lingkup hak ulayat lebih sempit dan terbatas, sementara hak penguasaan Negara ruang lingkupnya nasional dan meliputi semua sumberdaya alam yang terdapat dalam tanah air Indonesia.

\section{c. Pengaturan Hukum}

Pengelolaan Wilayah Pesisir dan PulauPulau Kecil Serta Pemberian Hak Atas Tanah Yang Berbatasan Dengan Pantai dan Pulau

Indonesia sebagai Negara hukum, termasuk kategori Negara hukum modern. Konsepsi Negara hukum modern secara konstitusional dapat dirujuk pada rumusan tujuan Negara yang termaktub di dalam pembukaan UUD 1945 yaitu : melindungi segenap bangsa Indonesia dan seluruh tumpah darah Indonesia, memajukan kesejahteraan umum, mencerdaskan kehidupan bangsa serta mewujudkan keadilan sosial. Nomrmalisasi tujuan Negara tersebut, khususnya memajukan kesejahteraan umum dan mewujudkan keadilan sosial antara lain termuat dalam Pasal 33 UUD 1945.

Pasal 33 UUD 1945 sebagai dasar hak penguasaan Negara mengatur tentang dasardasar sistem perekonomian dan kegiatan perekonomian yang dikehendaki dalam Negara Indonesia, tetapi Pasal 33 bukan sebagai sesuatu yang berdiri sendiri, melainkan berkaitan dengan kesejahteraan sosial. Berdasarkan pemikiran yang demikian, maka upaya memahami Pasal 33 tidak terlepas dari dasar pemikiran tentang kesejahteraan sosial (Bagir Manan, 1995 : 55). Atas dasar itu pula, sehingga tujuan hak penguasaan Negara atas sumberdaya alam ialah keadilan sosial dan sebesar-besarnya kemakmuran rakyat.

Keterkaitan hak penguasaan Negara dengan sebesar-besarnya kemakmuran rakyat menurut Bagir Manan (dalam Abrar Saleng, 2004: 17) akan mewujudkan kewajiban Negara

(1) Segala bentuk pemanfaatan (bumi dan air) serta hasil yang di dapat (kekayaan alam), harus secara nyata meningkatkan kemakmuran dan kesejahteraan masyarakat;

(2) Melindungi dan menjamin segala hakhak rakyat yang terdapat di dalam atau di atas bumi, air dan berbagai kekayaan alam tertentu yang dapat dihasilkan secara langsung atau dinikmati oleh rakyat;

(3) Mencegah segala tindakan dari pihak manapun yang akan menyebabkan rakyat tidak mempunyai kesempatan atau akan kehilangan haknya dalam menikmati kekayaan alam.

Ketiga kewajiban di atas, sebagai jaminan bagi tujuan hak penguasaan Negara atas sumberdaya alam yang sekaligus memberikan pemahaman bahwa dalam hak penguasaan itu, Negara hanya melakukan bestuursdaad dan beheersdaad dan tidak melakukan eigensdaad. Artinya secara a contrario, apabila hak penguasaan Negara diartikan sebagai eigensdaad maka tidak ada jaminan bagi pencapaian tujuan hak penguasan Negara yaitu sebesar-besarnya kemakmuran rakyat.

Lebih lanjut Bagir Manan merumuskan cakupan pengertian dikuasai oleh Negara atau hak penguasaan Negara sebagai berikut:

(1) Penguasaan semacam pemilikan oleh Negara. Artinya Negara melalui pemerintah adalah satu-satunya pemegang wewenang untuk menentukan hak, wewenang atasnya. Termasuk di sini bumi, air dan kekayaaan yang terkandung di dalamnya.

(2) Mengatur dan mengawasi penggunaan dan pemanfaatan; 
(3) Penyertaan modal dan dalam bentuk perusahaan Negara untuk usaha-usaha tertentu.

Apabila konsep Negara kesejahteraan dan fungsi Negara menurut W. Friedmann dikaitkan dengan konsepsi hak penguasaan Negara untuk kondisi Indonesia dapat diterima dengan beberapa kajian kritis sebagai berikut (Abrar Saleng, 2004 : 18-19) :

Pertama, hak penguasaan Negara yang dinyatakan dalam pasal 33 UUD 1945 memposisikan Negara sebagai pengatur dan penjamin kesejahteraan rakyat. Fungsi Negara itu tidak dapat dipisahkan satu dengan lainnya. Artinya melepaskan suatu bidang usaha atas sumberdaya alam kepada koperasi, swasta harus disertai dengan bentuk-bentuk pengaturan dan pengawasan yang bersifat khusus. Karena itu kewajiban mewujudkan sebesar-besarnya kemakmuran rakyat tetap dapat dikendalikan oleh Negara.

Kedua, hak penguasaan Negara dalam pasal 33 UUD 1945, membenarkan Negara untuk mengusahakan sumberdaya alam yang berkaitan dengan public utilities dan public service atas dasar pertimbangan : filosofis (semangat dasar dari perekonomian ialah usaha bersama dan kekeluargaan), strategis (kepentingan umum), politik (mencegah monopoli dan oligopoly yang merugikan perekonomian Negara), ekonomi (efisien dan efektifitas) dan demi kesejahteraan umum dan sebesar-besarnya kemakmuran rakyat.

Khusus berkaitan dengan kebijakan pemerintah dalam pengelolaan sumberdaya laut maka dapat dijelaskan bahwa paling sedikit terdapat tiga ciri dari kebijakan pengelolaan sumberdaya laut yang dipraktekkan selama ini, yakni (1) sentralistik, (2) didasarkan pada dokrin common property dan (3) mengabaikan pluralism hukum.

Sentralistik kebijakan menyangkut substansi sekaligus proses pembuatannya. Substansi kebijakan yang sentralistik tercermin pada kewenangan pengelolaan sumberdaya laut, setidak-tidaknya hak itu terjadi disektor perikanan. Disektor ini, proses perizinan maupun pejabat yang berwenang memberikan hampir seluruhnya berada di tangan pemerintah pusat. Kalaupun ada pendelegasian kewenangan kepada gubernur, hal itu sematamata dalam kedudukannya selaku wakil pemerintah pusat di daerah.

Demikian pula proses penetapan kebijakannya, hampir semuanya melibatkan pemerintah pusat. Indikasinya, kebijakan pengelolaan sumberdaya alam laut pada umumnya dikemas dalam bentuk undangundang, peraturan pemerintah, keputusan presiden yang dalam proses penetapannya semata-mata melibatkan aparat pemerintah pusat.

Kebijakan pengelolaan sumberdaya laut yang diasarkan pada common property sebagai ciri kedua juga mengandung sejumlah kelemahan. Dengan mendasarkan kebijakan pada dokrin common property maka laut diposisikan sebagai sumberdaya milik bersama. Konsekuensinya, laut diperlakukan laksana harta tak betuan dimana setiap orang leluasa melakkukan okupasi dan eksploitasi (open access). Karakteristik seperti ini sangat jelas dalam Undang-Undang Perikanan dan kebijakan lainnya. Ini pula yang antara lain melatar belakangi munculnya berbagai konflik dalam penggunaan sumberdaya terutama antara nelayan tradisonal dengan perusahaan penangkapan ikan.

Sebagai dasar pembentukan kebijakan pengelolaan laut, dokrin common property sesungguhnya mempunyai banyak kelemahan. Francois T Christy (dalam M. Arif Nasution dkk, 2005 : 105) mengungkapkan adanya empat akibat buruk dari suatu kebijakan pengelolaan sumberdaya laut yang didasarkan pada dokrin common property yaitu (a) pemborosan sumberdaya secara fisik, (b) inefisiensi secara ekonomi, (3) kemiskinan nelayan, dan (4) konflik antara pengguna sumberdaya.

Sementara pengabaian pluralism hukum, yang merupakan ciri ketiga dari kebijakan pengelolaan laut selama ini, menjelama dalam bentuk ketiadaan pengakuan terhadap sistem pengeloaan sumberdaya laut berdasarkan hukum adat. Padahal secara faktual sistem pengelolaan semacam itu masih dipraktekkan di berbagai daerah. Beberap contoh yang dapat 
dikemukakan, seperti sistem hak wilayah laut di Maluku atau perikanan Bagang dan romping di Sulawesi Selatan. Bahkan pada derajat tertentu, pluralism hukum dalam pengelolaan sumberdaya laut juga mengisyaratkan bahwa laut dapat menjadi obyek pemilikan tunggal, sesuatuyang berbeda secara diametal dengan doktrin common property.

Kemudian dalam sudut pandang peraturan perundang-undangan yang berkaitan dengan pengelolaan wilayah pesisir dan perairan pulau-pulau kecil adalah lahan di kawasan pantai yang tidak dibebani hak milik, dikuasai oleh negara dan digunakan sesuai peruntukan/fungsinya untuk kemakmuran rakyat. Peralihan status lahan dari lahan negara menjadi lahan yang dilekati hak yang bukan tanah negara dapat ditempuh dengan proses pelepasan atau pembebasan hak sebagaimana diatur dalam UU Pokok Agraria. Peraturan yang secara khusus mengatur tanah timbul secara alami memang belum ada. akan tetapi, mungkin dapat digunakan PP No. 8/1953 yang mengatur tentang pengusahaan tanah-tanah negara, sebelum ada peraturan lain yang baru.

Selain PP No. 8/1953 di atas, kiranya perlu juga diperhatikan UU No. 51/1960, tentang larangan untuk menggunakan tanah atau muka bumi bagi setiap orang yang tidak memiliki ijin yang sah dari penguasa tanah tersebut. UU No. 51/1960 melarang penggunaan secara liar bagi muka bumi dalam wujud tahapan manapun baik itu masih berwujud tanah yang tergenang air secara berkala, ataupun yang sudah berwujud tanah padat. Dengan adanya UU No. 51/1960 itu, Pemerintah Daerah berwenang mengambil tindakan yang perlu apabila ada pelanggaranpelanggaran hukum seperti tersebut di atas.

Tanah timbul, dalam tahapan yang manapun wujudnya, biasanya ada vegetasinya. Kalau ada yang menebangi pohon-pohon tetapi tidak langsung memanfaatkan tanahnya, orang tersebut dapat juga dituntut sebagai pelanggar hukum berdasarkan UU No. 5/967 dan diganti dengan UU No 41 tahun 1999 tentang Pokokpokok Kehutanan. Apabila sampai terjadi pencemaran ataupun kerusakan lingkungan hidup, tuntutan dapat juga didasarkan UU No. 4/1982.

Reklamasi pantai yang sudah dilakukan di Jakarta selama ini memang belum menimbulkan masalah dalam hukum tanah positif. Sebab reklamasi tersebut belum dalam arti yang sebenarnya, yakni menimbun pantai untuk menciptakan daratan baru. Sebagian reklamasi yang dilakukan adalah memunculkan kembali daratan yang terkikis abrasi. Sehingga tanah timbul tersebut tetap sama dengan peta wilayah yang lama sebelum abrasi. Dan juga sebagian lain merupakan daerah rawa atau ekosistem mangrove yang kebetulan berstatus tanah negara.

Hal diatas akan berbeda kalau yang direklamasi itu sepenuhnya laut. Sebab, hak atas tanah hanya berlaku sampai batas pasir pantai. Karenanya, laut tidak dapat dilekati dengan hak atas tanah. Pemegang hak atas laut sampai ke batas yang ditentukan oleh "Konvensi Hukum Laut PBB" yang telah diratifikasi Indonesia dengan UU No. 17 Tahun 1985 adalah negara. Jadi, seluruh kawasan perairan laut Indonesia dikuasakan kepada Kementerian Perhubungan untuk kepentingan pelayaran.

Kewenangan daerah dalam pengelolaan wilayah laut sebagai konsekuensi dari adanya desentralisasi pada bidang kelautan, jika tidak dicermati dengan baik akan berdampak terhadap pengkaplingan wilayah laut oleh daerah. Kenyataan tersebut, semakin diperparah oleh karena belum dituntaskannya pengaturan terhadap batas laut bagi daerah (Provinsi dan Kabupaten/ Kota) yang merupakan penetapan Undang- Undang Nomor 32 tahun 2004, sebagaimana dimaksud dalam Pasal 18 ayat (1) dan ayat (3). Hal tersebut berdampak terhadap wilayah-wilayah yang berkarakteristik kepulauan sebagai konsekuensi adanya penyebaran pulau-pulau (Lekipiouw, 2010).

Tanpa pengaturan, bisa dipastikan tidak ada jaminan keamanan dan kepastian hukum dalam berusaha, dan tentu saja akan selalu ada 
pihak yang merasa terpinggirkan kepentingannya. Mengingat potensi yang begitu besar dari perairan pesisir, baik potensi untuk "diusahakan" maupun potensi "konflik" yang ditimbulkan, pemerintah memandang perlunya pengaturan pengusahaan perairan pesisir, diantaranya dengan pemberian Hak Pengusahaan Perairan Pesisir (HP3).

Pemberian HP3 tersebut telah diakomodir melalui Undang-undang No 27 tahun 2007 tentang Pengelolaan Wilayah Pesisir dan Pulaupulau Kecil (UU PWP3K), kemunculan Undang-undang itu sendiri menimbulkan pro dan kontra. yang menjadi perdebatan ialah apakah pengaturan-pengaturan yang sudah ada tersebut sudah mencerminkan keinginan dan tujuan yang hendak dicapai oleh pasal 33 Undang-undang Dasar 1945 atau pemberian HP3 tersebut ternyata hanya akan seperti Hak Pengusahaan Hutan yang ternyata banyak merugikan masyarakat lokal dan Tujuan yang hendak dicapai Oleh Undang-undang Pokok Agraria ternyata tidak terlaksana.

Menurut Fauzi (1999), kebijakan hukum agraria sebagai mana tercantum dalam dalam UUPA sesungguhnya menentang kapitalisme yang melahirkan kolonialisme yang menyebabkan penghisapan manusia atas manusia. Selain itu, UUPA sekaligus juga menentang sosialisme yang dianggap meniadakan hak-hak individu atas tanah. Politik agraria yang terkandung dalam UUPA 1960 adalah politik populisme, yang mengakui hak individu atas tanah, namun hak tersebut memiliki "fungsi sosial". Melalui prinsip Hak Menguasai dari negara, pemerintah mengatur agar tanah-tanah dapat dipergunakan sebesar besarnya untuk kemakmuran rakyat sebagaimana termaktub dalam pasal 33 UUD 1945 (Noer, 1999).

Namun jika dilihat dari implementasinya maka yang tampak adalah penguasaan sumber daya (termasuk sumberdaya kelautan) selalu berada pada pihak-pihak yang memiliki ekonomi kuat sebagai subjek pengelola yang mengusahakan pemanfaatan dan eksplorasi, sedangkan nelayan berada pada posisi dipinggirkan. Salah satu aspek penting yang ada pada wilayah pesisir ialah akses pada sumber daya baik sumberdaya alam maupun sumberdaya perikanan, laut dalam hal ini perikanan merupakan sumber daya utama bagi masyrakat nelayan yang tinggal didaerahpesisir yang jika akses tersebut tidak dapat terpenuhi maka akan memasung hak-hak nelayan untuk memakmurkan hidupnya, sesuai dengan tujuan hukum agraria.

Dengan berlakunya Undang-undang PWP3K ternyata begitu banyak terjadi pro dan kontra, sehingga sanagat menarik untuk melihat dan menelaah bagaimana sesungguhnya pengaturan mengenai pengelolaan wilayah pesisir dan pulau-pulau kecil khususnya jika dikaitkan dengan hukum Agraria. Berdasarkan uraian latar belakang permasalahan tersebut diatas, maka dapat dirumuskan permasalahan sebagai berikut, (1) Meliputi apa saja cakupan Hak Pengusahaan Perairan Pesisir dikaitkan dengan hukum agraria Agraria dan Undangundang No 27 Tahun 2007 tentang Pengelolaan Wilayah Pesisir dan Pulau-pulau Kecil?. (2) Bagaimana pengaturan Hak Pengusahaan Perairan Pesisir dikaitkan dengan hukum agraria Undang-undang No 27 Tahun 2007 tentang Pengelolaan Wilayah Pesisir dan Pulaupulau Kecil.

Secara historis, penyebaran dan peningkatan jumlah penduduk yang menguasai kawasan pantai di Indonesia dimulai oleh para pedagang/nelayan atau para pendatang dari daerah lain atau para pengembara yang sering berlayar baik dari negara lain maupun yang berpindah-pindah dari pulau yang satu ke pulau-pulau lainnya. Secara berangsur-angsur sebagian dari mereka menetap dan menguasai lahan pada kawasan pantai yang diantaranya berupa hutan mangrove. Sampai saat ini sulit untuk melakukan pendataan kepemilikan lahan di kawasan pantai, karena sejarah, kondisi sosial-budaya dan faktor lain yang mengakibatkan masyarakat tradisional penghuni pantai berpindah-pindah. Pada perkembangan kepemukiman masyarakat pantai tersebut, saat ini perubahan status fungsi dan kepemilikan kawasan pantai dan hutan mangrove di wilayah-wilayah pesisir 
dihadapkan pada masalah-masalah belum adanya pengaturan oleh pemerintah tentang status kepemilikan Tanah (lahan) terutama yang berbatasan dengan pantai dan pulau , pengerukan dan reklamasi muara sungai dan pantai.

\section{PENUTUP \\ Kesimpulan}

Berdasarkan pembahasan yang sudah dibahas sebelumnya, maka penulis dapat menarik kesimpulan, yaitu sebagai berikut :

a. Pengelolaan wilayah pesisir dan pulaupulau kecil dalam pasal 4 menyatakan: (1). melindungi, mengkonservasi, merehabilitasi, meman-faatkan, dan memperkaya Sumber Daya Pesisir dan Pulau-Pulau Kecil serta sistem ekologisnya secara berkelanjutan;

b. menciptakan keharmonisan dan sinergi antara Pemerintah dan Pemerintah Daerah dalam pengelolaan Sumber Daya Pesisir dan Pulau-Pulau Kecil;

c. memperkuat peran serta masyarakat dan lembaga pemerintah serta mendorong inisiatif Masyarakat dalam pengelolaan Sumber Daya Pesisir dan Pulau-Pulau Kecil agar tercapai keadilan, keseimbangan, dan keberkelanjutan; dan

d. meningkatkan nilai sosial, ekonomi, dan budaya Masyarakat melalui peran serta Masyarakat dalam pemanfaatan Sumber Daya Pesisir dan Pulau-Pulau Kecil.

e. Kepastian hukum dan rasa keadilan masyarakat. masih diragukan bagaimana implementasi dan pelaksanaannya dilapangan, sehingga masih perlu diadakan penelitian lebih lanjut.

\section{Saran}

Berdasarkan kesimpulan yang sudah dibuat sebelumnya, maka penulis dapat memberikan saran, yaitu sebagai berikut :

Asas keterbukaan dimaksudkan adanya keterbukaan bagi masyarakat untuk memperoleh informasi yang benar, jujur dan tidak diskriminatif tentang Pengelolaan Wilayah Pesisir dan Pulau-Pulau Kecil, dari tahap perencanan, pemanfaatan, pengendalian, sampai tahap pengawasan dengan tetap memperhatikan perlindungan atas hak asasi pribadi, golongan dan rahasia negara;

Asas desentralisasi, Asas desentralisasi merupakan penyerahan wewenang pemerintahan dari Pemerintah kepada pemerintah daerah otonom untuk mengatur dan mengurus urusan pemerintahan dibidang Pengelolaan Wilayah Pesisir dan Pulau-Pulau Kecil;

Asas akuntabilitas, Asas akuntabilitas dimaksudkan bahwa pengelolaan wilayah pesisir dan pulau-pulau kecil dilakukan secara terbuka dan dapat dipertanggungjawabkan;

Asas keadilan merupakan asas yang berpegang pada kebenaran, tidak berat sebelah, tidak memihak, dan tidak sewenang-wenang dalam pemanfaatan sumber daya pesisir dan pulau-pulau kecil.

Sedangkan tujuannya pengelolaan wilayah pesisir dan pulau-pulau kecil dalam pasal 4 menyatakan: (1). melindungi, mengkonservasi, merehabilitasi, memanfaatkan, dan memperkaya Sumber Daya Pesisir dan Pulau-Pulau Kecil serta sistem ekologisnya secara berkelanjutan; (2). menciptakan keharmonisan dan sinergi antara Pemerintah dan Pemerintah Daerah dalam pengelolaan Sumber Daya Pesisir dan Pulau-Pulau Kecil; (3). memperkuat peran serta masyarakat dan lembaga pemerintah serta mendorong inisiatif Masyarakat dalam pengelolaan Sumber Daya Pesisir dan Pulau-Pulau Kecil agar tercapai keadilan, keseimbangan, dan keberkelanjutan; dan (4). meningkatkan nilai sosial, ekonomi, dan budaya Masyarakat melalui peran serta Masyarakat dalam pemanfaatan Sumber Daya Pesisir dan Pulau-Pulau Kecil.

Berdasarkan asas dan tujuan tersebut diatas dapat dikatakan bahwa pemberian hak yang ada diatur dalam UUPWP3K (dalam hal ini Hak Pengusahaan Perairan Pesisir) adalah telah berupaya memperhatikan ketentuan untuk melaksanankan amanat konstitusi "Bumi dan air dan kekayaan alam yang terkandung di dalamnya dikuasai oleh negara dan 
dipergunakan untuk sebesar-besar kemakmuran rakyat" yang tercantum dalam Pasal 33 ayat (3) UUD 1945.

\section{DAFTAR PUSTAKA}

[1] Bengen, D.G. (2001). Ekosistem dan Sumberdaya Alam Pesisir dan Laut. Sinopsis. PKSPL IPB. ISBN : 979-9561744.

[2] Dahuri, R.,J. R., S.P. Ginting dan M.J. Si. (1996). Pengelolaan Sumberdaya Wilayah Pesisir dan Lautan Secara Terpadu, Jakarta, Pradnya Paramita.

[3] Efendi, B. (1993). Kumpulan Tulisan tentang Hukum Tanah, Bandung, Alumni.

[4] Ernaningsih, W. (2009). Hak Menguasai Negara Atas Tanah, 2009, Cet I, Yogyakarta: Total Media.

[5] Etty Nur Agoes. (2004). Praktek Negaranegara atas Konsepsi Negara Kepulauan. Jurnal Hukum Internasional. Vol 1n Nomor 3, April 2004,UI.

[6] Fauzi, N. (1999). Petani dan Penguasa: Dinamika Perjalanan Politik Agraria Indonesia. Yogyakarta: Insist Press, KPA, dan Pustaka Pelajar.

[7] Harsono, B. (2002), Hukum Agraria Indonesia: Himpunan Peraturanperaturan hukum Tanah, Jakarta, Djambatan.

[8] Harsono, B. (2003), Hukum Agraria Indonesia: Sejarah Pembentukan Undangundang Pokok Agraria, Isi dan Pelaksanaannya, Jakarta, Djambatan.

[9] Johanis Leatemia. (2011). Pengaturan Hukum Daerah Kepulauan. Mimbar Hukum Volume 23 Nomor 3. Oktober 2011

[10]Mujiono, (1997), Politik dan Hukum Agraria, Yogyakarta, Liberty

[11]Nurlinda, I. (2009). Prinsip-prinsip Pembaruan Agraria; Perspektif Hukum, Jakarta, Raja Grafindo Persada.

[12]Parlindunagan, A.P. (1998), Komentar Atas Undang- Undang Pokok Agraria dilengkapi PP 40 dan 41 / 1996, Bandung, Maju Mandar.
[13]Peraturan Pemerintah Nomor 40 tahun 1996 tentang Hak Guna Usaha, Hak Guna Bangunan dan Hak Pakai.

[14]Peraturan Pemerintah 8/1953 tentang Penguasaan tanah-tanah Negara disebut dengan Hak Penguasaan.

[15]Peraturan Menteri Agraria 9/1965 tentang pelaksanaan Konversi Hak penguasaan Atas Tanah Negara.

[16] Santoso, U. (2005). Hukum agraria \& hakhak atas tanah, Jakarta: Kencana.

[17] Sherlock H Lekipiouw. (2010). Model Penataan Ruang Laut Daerah Berdasarkan Integrated Coastal ManagementSebagai Acuan Penyusunan Penataan Ruang Laut Pada Wilayah Kepulauan. Jurnal Sasi Vol. 16 No. 4. Bulan Oktober - Desember 2010

[18] Sudirman S. (2012). Hak Pengusahaan Perairan Pesisir (H.P.3), (Majalah Samudra), $\quad$ http:// bpsplpontianak.kp3k.dkp.go.id,

[19] Sunggono, B. (2006), Metodologi Penelitian Hukum, Jakarta, PT. Raja Garfindo Persada.

[20] Sugiyanto dan Sidik ,B P. (2006). Metodologi Penelitian Ilmiah, LAN RI. Jakarta.

[21] Suharto, Roem Lintang. (2013). Bahan Tayang Metode Penelitian Ilmiah Kediklatan.

[22] Undang-Undang Nomor 32 tahun 2004 tentang Pemerintahan Daerah

[23] Undang-undang Nomor 27 tahun 2007 tentang tentang Pengelolaan Wilayah Pesisir dan Pulau-pulau Kecil.

[24] Undang-Undang Nomor 1 tahun 2014 tentang Perubahan UU No. 27 tahun 2007. 
HALAMAN INI SENGAJA DIKOSONGKAN 